\title{
Jagannatha Dhama of India: A Study on History and Culture
}

\author{
Dr. Ratnakar Mohapatra* \\ Assistant Professor, Department of History, KISS, Deemed to be University, Bhubaneswar, PIN-751024, \\ Odisha, India
}

*Corresponding Author: Dr. Ratnakar Mohapatra, Assistant Professor, Department of History, KISS, Deemed to be University, Bhubaneswar, PIN-751024, Odisha, India

\begin{abstract}
Jagannath Dhama popularly known as Puri, is famous for its historic antiquities and religious sanctuaries in India. It is considered by millions of Hindus as one of the four Dhamas of India. This place is also well-known throughout the world for the celebrated temple of Lord Jagannatha. In fact, Jagannath Dhamahad also been maintaining itself as a stronghold place of Hinduism in India before the establishment of the Muslim rule in northern India. A good number of temples and mathasof medieval and modern periods are found to be established in the different parts of the Puri town. As a sacred place, this Dhama has been maintaining its highest pitch of glory from time immemorial to till today. So, from the cultural point of view, it is very interesting study for scholars of history. The aim of this paper is to study the history andculture of the Jagannatha Dhama of India in detail. Methodologically, both the primary and secondary sources have been used here to access the historical and cultural importance of Jagannatha Dhama of Odisha in Eastern India.
\end{abstract}

Keywords: Jagannatha, Dhama, religion, culture, Puri, Odisha, India.

Abbreviations: JASB: Journal of Asiatic Society of Bengal, OHRJ: Orissa Historical Research Journal

\section{INTRODUCTION}

Puri, the famous seat of Lord Jagannatha, is not only famous as the holy place of India but its surrounding is also treated as grand and splendid in the whole of world. The place of Puri is popularly known as Jagannatha Dhama, which became one of the four religious domains of India. It is situated on Latitude $19^{0} \quad 47^{\mathrm{m}} \quad 55^{\mathrm{s}}$ North and Longitude $85^{\circ} \quad 49^{\mathrm{m}} 5^{\mathrm{s}}$ East) in the state of Odisha. ${ }^{1}$ JagannathaDhama is exactly located about $59 \mathrm{kms}$. tothe south-east of Bhubaneswar, the capital city of Odisha. The Jagannatha Dhama is famous for its historic remains and religious sanctuaries in India. It is also well-known throughout the world for the celebrated temple of Lord Jagannatha, which stands on a prominent place near the sea-shore. This seaside tirtha by the wave lashed shore of the Bay of Bengal is an important sacred places of India. Odisha is like a lotus in the lake of Bharatavarsha and the site of Jagannatha temple is the heart of the flower. ${ }^{2}$ Besides the Jagannatha temple, there are also a number of temples and mathas (monasteries) noticed in the different parts of the Puri town. The place of Jagannatha Dhamais one of the important cultural centers of Odisha and it is also well known throughout India as a place of pilgrimage from the time of Yore. ${ }^{3}$ Dhamais called the sacred abode of Lord Vishnu or one of his avataras. The PuriDhama boasts of a continuous history from the third century BC to the present day and its unique monument like that of Jagannatha is famous in the world. Millions of pilgrims and tourists from all over India and abroad come to visit this holy place. ${ }^{4}$ Thisarticle attempts to focus on history and culture of Jagannatha Dhama of India.

\section{Methodology}

Both the primary and secondary source materials have been used in the writing of this article. The primary data have been collected through the practical observation, public opinions, hearsay accounts and interview methods during the period of experimental field survey. Photographs have also been taken from the most of the temples of the kshetra except those in the premises of Lord Jagannatha temple. The collected data with regard to the dates of temples are based on practical observations and the hearsay accounts through respondents. The data relating to the present work are Books, Magazines, Reviews, Journals, Periodicals, Texts, Proceedings, Manuscripts, Encyclopaedias, 
Antiquities, Records, Reports, and unpublished theses, which are available at the different educational institutions. The primary sources are mainly the archaeological sources, literary sources (Puranas, Texts), Gazetteers, on the spot study, public opinions, hearsay accounts of respondents, practical observations etc.

\section{ANALYSIS AND DISCUSSION}

\subsection{Historicity of Jagannatha Dhama}

In the past the place of present Jagannatha temple was said as PurusottamaKshetra (Puri). In fact, the Jagannatha Dhama is a coordinating place where all the Hindu gods and goddesses are worshipped. The main Jagannatha temple is situated in the centre of the kshetra and around it are a number of streets (sahis). The placeof Puri town is covered by the traditional seven sahis, which are mostly inhabited by the priests and other sevakas of Lord Jagannatha temple. It may be the nucleus and as L.S.S.O' Malley has aptly referred that it has spread out somewhat in the shape of fan. ${ }^{5}$ The traditional sahis of the kshetra are Harachandisahi on the west, Bali sahi on the south, Dolamandapasahi and Mochisahi on the east, Markandesvarasahi and Cudangasahi on the north and so on .

The earlier name of Jagannatha Dhamawas Nilachala (Blue-Hill), on which the present Jagannatha temple stands. ${ }^{6}$ The name Nilachala however, is not now in common use. It is one of the fascinating aspects of the cultural history of Odisha that religion became the part of Odishan kingship. The early development of this relationship can be traced back to the Somavamsi period. It is said that in order to strengthen and legitimize their rule in the Puri region, which was then known as Purusottamakshetra,the rulers have utilized the religious faith of the people upon Lord Purusottama. The word 'Purusottama' is the name of the divinity, the noblest male deity of this kshetra.After the construction of great temple of Lord Purusottama at this kshetra, the place became famous as the abode of Lord Purusottama or Purusottamakshetra. In the Nagari Copper plate charter of Anangabhima Deva-III dated Saka year 1152 i.e. corresponding to 1230 A.D., the place is recorded as Purusottamakshetra. $^{7}$

During the reign of Anangabhima Deva III (1211 to 1238 A.D.), the presiding deity Purusottama was called as Jagannatha, the Lord of the world. The Kurmesvara temple inscription (dated 1230 A.D.) is the first record (so far known to us) to refer Jagannatha as the presiding deity of the kshetra. ${ }^{8}$ This inscription also clearly refers to SriJagannatha as the real king of Ganga kingdom and Anangabhima Deva-III as the Rout or deputy of Lord Jagannatha. The name was changed from Purusottama to Jagannatha to suit the different sections of religious beliefs such as Buddhists, Jainas, Shaivas, Vaisnavas and Shaktas. At that time, Muslim powers of the frontiers of Ganga kingdom were powerful and called the Ganga kingdom as the kshetra of Jagannatha. After the complete occupation of Odisha by British in 1803 A.D., the British officials recorded it (kshetra) as the city of Jugarnnath. Initially, the kshetra was also recorded as Purusottama by them but in later period they recorded it in various names such as Jekarnat, Juggernaut, Juggarnath-poore etc.

Sir Thomas Roe, who visited India during the reign of emperor Jahangir (1603 A.D. - 1627 A.D.), has described to the place as the chief city called 'Jekanat'. Similarly an English visitor William Bruston, who came here (Puri) in 1633 A.D., has called it 'the great city of Juggarnat'. William Hamilton in his 'Description of Hindostan' written in 1820 A.D. mentions the city as Juggarnath, Juggannath-poor and Poore. While Andrew Stirling has referred to it both as Jugarnath-Poore and simply Poorel. ${ }^{9}$ L.S.S.O' Malley writes 'Evidently, therefore, the later name commended itself to popular taste as a handy abbreviation and displaced the older and more correct name Jagannatha, the Lord of the world, whose temple has made the town famous throughout India. ${ }^{10}$ The present name of this kshetra (Puri), which seems to have been derived from the British recorded word i.e. Jugarnath-poore. So this place is popularly known asJagannatha-Puri in the whole of India.

\subsection{Sanctity Of Jagannatha Dhama}

The sanctity of the place of Purusottama (Jagannatha) exists from the prehistoric period, where the tradition cannot reach. ${ }^{11}$ In the Mahabharata, Vanaparva, there is a reference to the site of Purusottamakshetra, which has been mentioned as the place of Yajnavedi which is near the sea in Kalinga. ${ }^{12}$ Jagannatha is found mentioned in the chapter entitled 'UttaraKhanda' of the epic Ramayana, where Lord Rama asks Vibhisana to worship Jagannatha, who is the family deity of the Ikshyavaku dynasty. ${ }^{13}$ The glory and sanctity of Lord Purusottama and its kshetraalso find mention in many works. 
From the very beginning, this holy place has been dominating by the different religious sects, such as Buddhists, Shaivas, Shaktas ,Vaishnavas, etc. According to Robert Dunbar, Puri (Purusottamakshetra) is the Mecca of the righteous Hindus, one of the original strongholds of Buddhism and the home of Juggarnath, the 'Lord of the world'. ${ }^{14}$ Due to the cultural importance, this site attracts to the orientalists, scholars, archaeologists and antiquarians. It is an interesting place, which few cities can boast.

It was generally believed that the temple of Purusottama (Jagannatha) was built over a Buddhist Stupa. Puri seems to have been an intermediate place of pilgrimage, where the pilgrims from Ceylon used to stay here for going to Bihar, the birthplace of Lord Buddha. ${ }^{15}$ William Hunter says that 'Juggarnath, the presiding deity of the kshetra, represents with unmistakable clearness that coalition of Brahmana and Buddhist doctrines, which forms the basis of Vishnu Worship. ${ }^{16}$

The prior to the advent of Vaishnavism, however, the place of Puri was a ShaktaPitha as substantiated both by literary records as lists of ShaktaPithas in Tantric Texts and by archaeological evidences. H.V.Stietencron has pointed out that Vimala as the presiding deity and her temple was situated on Nilacala. ${ }^{17}$ Both Jagannatha and Goddess Vimalaare the presiding deities of that kshetra. ${ }^{18}$

In respect to archaeological evidence, some of the most important Shakta images in this kshetra are the SaptaMatrikas, presently preserved in a modern shrine on the edge of the Markandesvara tank, assignable to the late $10^{\text {th }}$ century AD. The Shakta environment of JagannathaDhama is also apparent in the belief that the Jagannatha temple is protected by astashaktisnamely, SarvaMangala, Ardhasini, DakshiniKalika, BattaMangala, Vimala, AlamChandi, Marchika and Harachandi. ${ }^{19}$ Other minor Shakta shrines of the Dhama are Lakshmi, Syamakali, Indrani, Rama Chandi, Bhubanesvari ,Durga ,etc.

The popularity of the Puriincreased after the construction of a grand temple of Purusottama (Jagannatha) by Chodaganga Deva, the founder of the Ganga dynasty of Orissa. ${ }^{20}$ The Copper plate charters of his successors record that the construction work of the present temple for the God Purusottama was initiated by Gangesvara i.e. Chodaganga Deva (1077 AD to 1147 AD). The earliest reference to the construction of the present great temple of Purusottama is found in the Dasagoba charter of Rajaraj-III dated $1198 \mathrm{AD} .^{21}$ The construction work of the present great temple Lord Jagannatha was carried on by his successors and lastly it was finishedin the last decade of $12^{\text {th }}$ century by Anangabhima Deva II.After one hundred years of the initiation of the construction work of the present great temple, Anangabhima Deva-III, the Ganga ruler consecrated the great temple of Sri Purusottam at Puri. ${ }^{22}$ The temple of Lord Jagannath is the best example of Kalinga style of architecture of OdishainEastern India. The style of Jagannath temple follows the Nagara style of temple architecture of north India but with some beautiful variation.The heart of Puri town is the great Jagannatha temple, which stands at one end of the BadaDanda or the Grand Road.. In the sanctum (garbhagriha), Jagannathais the presiding deity. At Puri Jagannatha, who is an aspect of Vishnu, the Lord of world,is worshipped as Lord Krishna, the eighth avatara of Vishnu. ${ }^{23}$ In Odisha, Sri Jagannatha temple of Puri is popularly known as Srimandira.

Navakalevara is the most important ceremony of Lord Jagannatha of Puri in Eastern India. The word 'Navakalevara', which literally means 'New Body' is made out of a newly cut Neem tree. The newly made wooden images of Lord Jagannatha, Balabhadra, Devi Subhadra and Sudarsana of the Jagannatha temple are traditionally celebrated by Daitasas Navakalevara. Particularly, the suddhasavaras (Daitas) are permitted to perform some rituals in the Jagannatha temple mainly at the time of Navakalevara festival. The Navakalevara ceremony of PuriJagannatha temple is the prominent ritual, which is not found prevailed in any other Vishnu temples of India. Sri Jagannatha temple of Puri is popularly known as Srimandira. The Chaturdhamurtis on the 'Ratnasimhasana' of Srimandirai.e.Jagannatha, Balabhadra, Subhadra and Sudarsana are prepared out of Neem wood, which is the best wood available for making divine images. ${ }^{24}$ As per the Silpasastras, the wooden images of Lord Jagannatha, Balabhadra, Subhadra and Sudarsana are required to be renewed from time to time. The Navakalevara ceremony is the periodical renewal of the DaruDevatas of the 'ChaturdhaMurtis' of PuriSrimandira. On the basis of tradition, the Navakalevara (New Body) ceremony is observed like the life of human being's event of "death and re-birth" of Lord Jagannatha. Generally, the Navakalevara ceremony of Lord Jagannatha of Puri is observed in every 12 to 19 years accordingly the astrological calculation. Looking at their roughhewn style, scholars feel that originally the icons were tribal deities that were absorbed into the Hindu pantheon and the main icon was 
transformed into an avatar of Vishnu. ${ }^{25}$ The myth of Lord Jagannatha indicates the tribal origin.Navakalevara ceremony of Lord Jagannatha of Puri is the symbolic of the traditional Vedic worship mixed with tribal worship of India.

The ceremonies of Lord Jagannatha temple have fascinated visitors for centuries. The famous RathaYatraof Lord Jagannathais observed in the month of Ashadha in June/July, just as the first monsoon rains begin to fall over the land. Jagannath, Balabhadra and Subhadra ride in chariots (rathas) with brightly coloured canopies, majestically moving down the road to the sound of conches, bells, drums, and chanting of mantras. ${ }^{26}$ Large numbers of pilgrims arrive and this huge crowded chaotic festival has justified the word 'Juggernaut'. At the time of RathaYatra, non-Hindus can see the images of Jagannath Trinity. Jagannath'schariot is namedNandighosh, which iscanopied by the wheel of the Sudarsana Chakra. Balabhadra's chariot is saidTaladhvaja.Devi Subhadratravels in the 12 wheeled Padmadhvaja (Devadalana) ratha with a red and black canopy. The duration of the RathaYatra festival is for 10 days starting from the $2^{\text {nd }}$ to the $10^{\text {th }}$ day of the shuklapaksha, the bright fortnight of Ashadha, in June/ July.

Puri town is studdedwith minor places of architectural or antiquarian importance. The main attention has been so exclusively immersed by Jagannatha temple that little has been done for any other sacred spots. There are, however, a great number of insignificant small temples, which enjoy the reputation of considerable sanctity. Among these the most noted are the eight Shaiva shrines. They are viz. Markandesvara, Yamesvara, Nilakanthesvara, Belesvara, Kapalamocana, Vilvesara, Isanesvara and Patalesvara. ${ }^{27}$ W.W.Hunter records the existence of temples dedicated to the worship of Siva and his female energy in their sixteen different manifestations in the kshetra of Purusottama. The male Sambhus are represented by the images of Markendesvara, Kapalamochana, Lokanatha, Yamesvara, Nilakanthesvara, Trilochana, Bhutesvara and Patalesvara; the female chandis have the names of Mangala, Vimala, SarvaMangala, Kali, Dhatri, Kamakshya, Ardhaasti and Bhavani. ${ }^{28}$ The place of Puri is one of the greatest centres of Vaishnava worship. Though the kshetra primarily associated with Lord Purusottama (Jagannatha), it contains a number of temples sacred to the worship of all other Principal deities in the Hindu religion. ${ }^{29}$ The minor Vaishnava shrines of the kshetra are vizNarasimha, Nilamadhava, Narayana, Sakhi-Gopinatha, Yajna-Narayana, Gopinath, BenuMadhava, etc. Other miscellaneous temples, which are dedicated to different sects such as Gundicha, SuryaNarayana, Siddha Mahavira, DariaMahavira, Ganesha, etc. The pious Hindus also do visit the above sacred shrines of the Dhama of Lord Jagannatha.

A larger numbers of mathas or religious monasteries belonging to the different sects are also established at the place of Jagannatha Dhama. According to Madalapanji, the palm leaf chronicle of the temple of Lord Jagannatha, the mathas were originally founded with the purpose of imparting education to disciples and give shelter to pilgrims, feeding travellers, ascetics and Beggars. ${ }^{30}$ The main purpose of the establishment of mathas is to impart religious instructions to the disciples and generally of encouraging a religious life. ${ }^{31}$ But the mathas of Puri were originated and developed as inseparable institutions, traditionally associated with the worship of Purusottama or Jagannatha. It is said that in the $8^{\text {th }}$ century AD, Sankaracharya established the first mathas at Puri.

According to tradition, Sankaracharya (788-820 AD) in course of his spiritual conquest of the whole of India, stayed at this kshetra (Puri), which was well-known by that time as a chief centre of religion and culture. He founded one of his four pithas called Govardhanapitha here, which has remained in existence till today. ${ }^{32}$ Thispitha is now called as Govardhanamatha of Puri.

Being attracted by this far-famed place, RamanujaAcharya also came to this kshetra during the reign of ChodagangaDava. He was also interested to establish a pitha at Purusottamakshetra like the great Sankaracharya. The visit of Ramanuja to Puri is also indirectly proved by the existence of two mathas there, one namely Ramanujamatha, which is said to have been founded by himself and the other being Emaramatha, which is attributed to Govinda, the favourite disciple of Ramanuja.

Nimbark, another great Vaishnava preacher of South, who lived a few years after Ramanuja is said to have visited to this kshetra to establish a seat on his religious faith here. Out of the five important mathas of Puri, one is RadhaVallabha for the sect of Nimbarka. Jayadeva, the famous poet, who was a follower of Nimbarka wrote his famous Gita-Govinda with staying at this matha.

MadhavaAcharya or Tirtha, the latest of the four famous Vaishnava preachers of South India is also said to have visited Puri during reign of Narasimha Deva I (1238-1264 AD), the Eastern Ganga king 
of Orissa. Sri Ramananda also visited Puri in the $14^{\text {th }}$ century AD. He established a training centre at Puri to train young people in order to protect the temple of Jagannatha from Muslim attack. During the reign of King Prataparudra Deva, Sri Chaitanya from Bengal came to Jagannatha-Puri. He stayed in this kshetra for a period of 24 years out of which he traveled for only 6 years to Mathura and Vrindavana respectively. He was staying at KasiMisralaya, which is called as Radhakantamatha at present. Nanak, the Guru of Sikh religion also visited to Puri and established Baulimatha and Mangumatha here. Tulasi Das, the great saint of north India also came to Puri.

Other mathas like Sri Ramadasamatha, Uttaraparsvamatha, Siddhesvaramatha, Odiamatha, Siddhavakulamatha, Rmjimatha, etc.are noticed in the Puritown. After the establishment of mathas in this place, a large number of devotees and travelers from all over India as well as abroad came to visit Puri as a sacred place of Hinduism in eastern part of India.

\subsection{Culturalsignificanceof Jagannatha Dhama}

A group of tribals are found to be resided at the place of Puri town and they are associated withvarious festivals and ceremonies of Lord Jagannatha. ${ }^{33}$ The Brahmins hold on the daily rituals butShabarsinvolve in many of the rituals and festivals. They search for the neem trees for carving and painting the new images and playing a major role during the Carfestival. ${ }^{34}$ This Shabar servants of Lord Jagannatha are called Daitas. The kshetra of Jagannatha is commonly inhabited by priests as well as other sevakasof Lord Jagannatha. Probably people of all castes reside in the different parts of the kshetra. According to tradition, people of the Kalingan society have been worshipping three gods viz the home deity, the village deity and the mass deity. ${ }^{35}$ The Mother goddess of home who protects the family. She stays in a secret place of the residence. On each and every auspicious occasion she is to be worshipped first. Another deity is the village deity who is worshipped by the entire villagers. This deity generally resides in the boarder of the village.Besides these two types of deities another deity named mass deity i.e. 'RastraDevata' or LokaDevata was being worshipped with deep reverence as the god of state. He was worshipped by the entire population of the state irrespective of caste, creed and colour. He is above all deities and also worshipped in the concept of a human being. That is why; $\mathrm{He}$ is a Greatman or Purusottama(Jagannatha). This Devata required a large number of sevakas known as Niyogas(sevakas). According to Madalapanji, the temple chronicle of Lord Jagannatha written in Odia language, king Anangabhima Deva III of the Ganga dynasty had established 36 Niyogas known as Chhatisa Niyoga. ${ }^{36}$ The term Chatisa-Niyoga refers to thirty-six categories of servants (sevakas) employed in the service of Lord Purusottama (Jagannatha). Infact, at present Lord Jagannatha is being worshipped by the thirty-six categories of people (ChatisNiyogas) as it is assumed that there were 36 categories of people present in Srikshetraand its vicinity. People of the Puritownwere divided into thirty-six categories as per their occupations. The names of all categories are mentioned below.

They are such as Rajguru (Brahmin), Purohita (temple priest), Mahajana, Khuntia (who watches the deities), Mekap ( in charge of store), Padhiari( in charge of guarding the temple), Daita (in charge of Anabasara and Navakalevara), Paika (soldier), Sunari (goldsmith), Kacara (bangler), Gudia(sweet man), Teli (oil man), chitrakara (painter), Bauri, Bhandari (barber), Gauda (milk man), Mali (florist), Liari, Pandari, Kumbhara (soil pot maker), Paöara(maker of Silk cloth), Keuöa (fisherman), Kansari (brazier), Roul, Dhoba(washer man), Badhei(carpenter), Halua (cultivator), Sahukar (shop keeper), Matia (labour), Hadua (salesman), Gola (preserver), Bindhani (blacksmith), Khandayata (soldier), Nayak(astrologer), Bhoi (lower caste) and Dora.

In the past, Devadasi system / tradition was prevalent in the Jagannatha temple of Puri. The Devadasisare treated as the existing wives of Lord Jagannatha. The social statusof Devadasisis very high for the performance of their traditional divine dance and music before Lord Jagannatha. The system of devadasi dance has a spiritual origin. When the system thus established became a custom, the descendants of the original damsel continued it and were known as Devadasis, the maid servants or female attendance of Lord Jagannatha. ${ }^{37}$ The dance of devadasis (dancing girls) is a unique cultural tradition of Lord Jagannatha temple of Puri.

The traditional paintings of Jagannatha Dhamaindicate the amalgamation of three cultural traits such as Shavara, Dravidian and Aryan culture and all these three traits have contributed immensely to our cultural heritage. ${ }^{38}$ The temple of Lord Jagannatha is lavishly depicted with the traditional paintings of Odisha. The walls and ceilings of the jagamohana as well as the natamandapaof the 
Jagannathatemple are elegantly depicted with paintings of various gods and goddesses. In these paintings, the ten incarnations of Lord Vishnu are depicted. They are such as Matsya (fish), Kachhapa (tortoise), Varaha, Narasimha, Vamana, Parasurama, Rama, Balarama Buddha and Kalki. A few Krishna lila scenes are also depicted in the jagamohana ceiling of the temple. A few modern paintings depict the mythological scenes, which are also found in the natamandapa. There are numerous paintings, however, including the Kanchi-Kaveri expeditions of king Purusottama Deva depicting the interview between the milk-woman (Manikagauduni) and cavalries on horseback (Jagannatha and Balabhadra). The relief is elegantly depicted with traditional PattaStyle paintings of Odisha. The local painters are engaged on hereditary basis and are known as "Sevakas" of SriJagannatha.

People of the Jagannatha Dhamanot only worship the Lord Jagannatha but they also worship all types of Hindu gods and goddesses. Hence a large number of temples are erected in the different parts of the kshetradedicated to those divinities. All the extant temples of Jagannatha Dhama exhibit the Kalinga style temple architecture of the state of Odisha.

In the post Gupta period, Shaivism became the strongest Hindu sectarian religion in Odisha as well as in the kshetra of Lord Purusottama. It was the dominant religion in central Odisha from the $6^{\text {th }}$ century A.D. onwards and reached the peak of its glory during the Somavamsi period in the $10^{\text {th }}$ and $11^{\text {th }}$ century A.D. During this period, most of the ancient Shaiva temples of the kshetra were constructed by the Somavamsi rulers of Odisha. Saktism was closely related to Shaivism, although its traces may reach back to an even more distant past. The female deities were worshipped by the lower strata of society. The Shaktas gained their greatest influence and were most generously supported by the rulers of Odisha extending during the period from the $8^{\text {th }}$ to the $16^{\text {th }}$ century A.D. Vaishnavism entered into the Srikshetraregion as a predominant religious faith later than that of Shaktacult and it over shrouded all the Brahminical sects. The Ganga kings fully turned towards Vaishnavism in the early part of the $12^{\text {th }}$ century A.D. and it remained as the religion of the majority of people of Odisha. Vaishnavism advanced towards Odisha from the South and the West. Scholars mostly contend that the Odishan Vaishnavism is an offshoot of Buddhist philosophical doctrines and religious practices characterized by Tantric form of worship. ${ }^{39}$ Like Shaiva, Shakta and Vaisnava deities, other deities are also being worshipped in the kshetra. They are Ganesa, Surya, Hanumana etc. The inhabitants of the kshetra (Puri) were the worshippers of Panca Devatas namely Siva, Visnu, Durga, Surya and Ganesa who were enshrined in different parts of the kshetra. Hence, the entire kshetra became full of temples of various sects of Hinduism. The cult of Jagannatha assimilated the essence of all the sects and evolved as a major religion of India.

PuriDhama boasts a continuous history from the third century B.C. to the present day and its unique monument like that of Jagannatha, which is famous in the world. So millions of pilgrims and tourists from all over India and abroad come to this holy Dhama and the flow is the greatest during the Carfestival of Lord Jagannatha celebrated in the month of June-July of every year. Puri has been considered as an important place of Hindu worship of the country. The sanctity and historicity of the Jagannatha Dhama together with its ideal healthy environment have been a suitable resort through the ages for the travelers and pilgrims alike. The history of religion of the Jagannatha Dhama is of special interest, as at one time or another it has been the home of widely different cults as Animism, Vedic Brahminism, Buddhism, Jainism and Puranic Brahminism, including Shaivism, Sun worship and Vaishnavism. ${ }^{40}$ JagannathDhamagradually grew to be a place of religious tolerance accommodating different sects such as Hinduism, Buddhism and Jainism.Besides these, some other sacred spots of the Jagannatha Dhama are vizSvargadvara or the gateway to heaven, Sveta Ganga, Indradyumna tank, Narendra tank and Chakra tirtha. The pious Hindus also visit the above sacred places of the Jagannatha Dhama.

Puri is also well-known as Jagannatha Dhama, which became famous as one of the four religious domains of India. Its fame afterwards out stepped the boundary of India. This Dhamahad also been maintaining itself as a stronghold place of Hinduism in India before the establishment of the Muslim rule in northern India. ${ }^{41}$ E. Hein considers that Purusottamakshetra, the abode (site) of Lord Purusottama (Jagannatha) at the coast of Bay of Bengal in Odisha as one of the most prominent centers of Hindu pilgrimage. ${ }^{42}$ From the cultural point of view, India is divided into fourreligious centers, which were recognized as four religious domains (dhamas) situated in the four directions of India. Those are called Badrinatha Dhama, Ramesvaranatha Dhama, Dvarikanatha Dhama and 
Jagannatha Dhama existed in the north, south, western and eastern sides of India respectively. Traditions describe that Badrinatha Dhama was originated in Satyayuga where Lord Jagannatha was in meditation, Ramesvaranatha in Tretaya where Lord Jatannatha took his full bath, Dvarika in Dvapara where Lord Jagannatha was in deep sleep and PuriDhama in Kali-yugawhere Lord Jagannatha is taking various kinds of delicious and sacred food (Mahaprasada). Therefore, Badrinatha is regarded as the place of meditation, Ramesvara as the place of bathing, Dvarika the place of sleeping and Jagannatha Dhama the place of eating of Lord Jagannatha respectively. The sight Ananda Bazar of Lord Jagannatha temple complex is conceived and created as a mass hotellargest in the world.

\section{CONCLUSION}

We come to known from the above discussion that the religious sanctity of Jagannatha Dhamasurprises from the remote past. Various earlier works and extant monuments of the Puri town prove its cultural identity. In fact, Puritownhad been sustaining as a stronghold place of Hinduism in India earlier the founding of the Muslim rule in northern India. During the reign of Anangabhima Deva-III (1212 AD to 1238 AD), the place of Puri townwas called as Jagannatha Dhama of Eastern India. This name was also continued during the period of Muslim rule in India. At that time it was also called as Jagannatha Dhama or Jagannathakshetra of India. After the occupation of Odisha by British in 1803 AD, Puri town was recorded as Jagannathapooree. The present name of Puri seems to have been derived from the British recorded word i.e. Jugarnath-poore. So this place is now popularly known as Jagannatha-Puri (JagannathaDhama ) in the whole of India. The Jagannatha Dhamaof Odishacan not be accepted by scholars as a Buddhist site as evidences are not availableregarding the fact. The prior to the advent of Vaishnavism, the place of Jagannatha Dhamawas a Shaktapithaasevidenced both by the literary and archaeological sources. In fact, the cultural importance of the Jagannatha Dhamawas increased after the establishment of temples and mathas of the different sects. Though the place of Puri townwas chiefly associated with Lord Purusottama (Jagannatha), it holds a number of temples sacred to the worship of all other major deities of the Hindu religion. The extant insignificant small temples of the Dhama enjoy the reputation of considerable sanctity. Most of the ancient Shaiva temples of the Purimentioned in the factwere constructed by the Somavamsi rulers of Odisha. Besides the Lord Jagannatha temple, some minor Vaishnavite shrines like Narasimha, Nilamadhava, Narayana, Sakhi-Gopinatha, Yajna-Narayana, Gopinath, BenuMadhava, etc. are found noticed in the Puri town. Other miscellaneous temples dedicated to different sects such as Gundica, SuryaNarayana, Siddha Mahavira, Daria Mahavira ,Ganesha, etc. are also found to be erected in the Dhama of Jaganntha. The Navakalevaraceremonyof Jagannatha temple reveals the real devotion, sincerity and perseverance of the Daitas, Daitapatis, priests, and devotees to Lord Jagannatha. This ceremony is considered as the symbolic confluence of the Tribal-brahminical rites. It is not only a unique ceremony of Odisha but also of the whole of India. The famous RathaYatra of Lord Jagannatha is observed in the month of Ashadha in June/July. Large numbers of pilgrims from India and abroad come this Dhamaand this massive crowded chaotic festival has identified the word 'Jagannatha' or Lord of world. So, being an important historical site, the Jagannatha Dhamadrawsthe attention of historians, archaeologists, scholars and pilgrims of entire globe. Really, the historical and cultural prominence of the Jagannatha Dhama in the ancient period is enigmatic, but from the early medieval period this place boasts a continuous history as evidenced from the available monuments, which are conspicuously discernible. The Jagannatha Dhama is considered as the most sacred place than the other holy places of India. On the whole, from the cultural point of view, the place of Jagannatha Dhamaof Odishacan be rightly considered by scholars as one of the prominent religious domains of India.

\section{ACKNOWLEDGEMENT}

I am deeply obliged to Sri JagabandhuPadhi, Dr. Bhaskar Mishra, Prof. K.S. Behera (late), Prof. C.R. Mishra (late), Prof. H. K. Satapathy, Prof. K.K. Basa, Dr. B.K. Ratha, Prof. P.K. Nayak and Prof. ByomakeshTripathy for their encouragement and valuable suggestions in the preparation of this article.

I express our profound reverence to Prof. AchyutaSamanta, the Hon'ble Founder of KISS, Deemed to be University, Bhubaneswar who encouraged me for the writing of this article. 


\section{REFERENCES}

[1] Senapati, N.\&Kuanr, D.C. (eds.), Orissa District Gazetteer; Puri, , Orissa Government Press; Cuttack, p.771, (1977)

[2] Sen Gupta, S., CHAAR VDHAM: A Guide to the Hindu Pilgrimages, New Delhi, p.131, (2003,).

[3] Orissa Historical Research Journal, Vol.III, No.1, Orissa State museum, Bhubaneswar, pp.6-12, (1948).

[4] Malley,L.S.S. O' , "Puri"; A Gazetteer, Bengal Secretariat Press, 1908, Reprinted in Usha Publications, New Delhi, p.1, (1984).

[5] Ibid, p.290, (1984).

[6] Mitra, R.L., The Antiquities of Orissa, Vol.II, New Delhi, p.168,(Reprint -1984).

[7] "The Nagari Copper Plate of Anangabhima Deva-III dated 1230 A.D.”, in Sircar, D.C. (ed.), EpigraphicaIndica, Vol.XXVIII, pp.235-258.

[8] "The Kurmesvara Temple Inscription of Anangabhima Deva-III dated 1230 A.D.", in South Indian Inscriptions, Vol.V, No.58, quoted by Das, K.C. ,Orissa Review, Orissa Government Press; Cuttack, , p.33, (July;1988).

[9] Stirling, A., Account of Orissa Proper or Cuttack (Geographical, Statistical and Historical), London, p.18, (1846).

[10] Malley, L.S.S. O', op.cit, p.287, (1984).

[11] Ganguly, M.M., Orissa and Her Remains (Ancient and Medieval), Calcutta, p.398, (1912).

[12] Mahabharata; Vanaparva, Chapter-114, Slokas 22-24, Poona, (1955).

[13] Sen Gupta, S., op.cit., p138, (2003)

[14] Dunbar, R., Temples of JagannathaPuri, New Delhi, , p.1, (India Reprint 1999).

[15] Ganguly, M.M., op.cit, p.401, (1912).

[16] Hunter, W.W., The Indian Empire, 1883, quoted in Malley, L.S.S.O., op.cit, p.90,(1984).

[17] Stietencron, H.V., "The Advent of Vaishnavism in Orissa”, in Eschemann, A., Kulke,H.\&Tripathy, G.C. , (eds.), The Cult of Jagannatha and Regional Tradition of Orissa, New Delhi, pp.25-27, (1978).

[18] Sircar, D.C., The ShaktaPithas, Calcutta, p.68, (1971).

[19] Mitra, R.L., op.cit, p.230, (1984).

[20] Chakravarti, M.M., “The Date of the Jagannatha Temple in Orissa”, in JASB, Vol. LXVII, pp.328-331, (1898).

[21] EpigraphicaIndica, Vol. XXXI, New Delhi, pp.249-262, (1892).

[22] Rajaguru, S.N., Inscriptions of the Temples of Puri and Origin of Sri Purusottama-Jagannatha, Vol.1, Sri Jagannatha Sanskrit Visvavidyalalya, Puri, p.29, (1992).

[23] Sen Gupta, S., op.cit, p.134, (2003).

[24] Mitra, R.L., op.cit, pp. 202-204,(Reprint-1984).

[25] Sen Gupta, S., op.cit, p.135, (2003).

[26] Ibid, p.146, (2003).

[27] Mitra, R.L. op.cit,. p.230, (1984).

[28] Hunter, W.W., "Orissa”, Extracts Reprinted in N.K.Sahu (ed), A History of Orissa, Vol.1, Calcutta, p.58, (1956).

[29] Pattanaik, P.K., "Historic monuments in the Ksetra of Jagannatha", in Das, M.N. (ed), Side Lights on History and Culture of Orissa, Cuttack, p.509, (1977).

[30] Mohanty, A.B., Madalapanji (Odia), Utkal University; Bhubaneswar, pp.30-33,(1969).

[31] Malley, L.S.S. O', op.cit, p.112, (1984).

[32] Mahapatra, K.N., "JagannathaPuri. As a Centre of culture through the ages", in. OHRJ, Vol.VI, January; No.4, pp.269-297, (1958).

[33] Sen Gupta, S., op.cit, p.135, (2003).

[34] Ibid, (2003).

[35] Padhi, B.M.,Religious Tradition in Eastern India Lord Jagannatha, Jagannatha Research Institute; Bhubaneswar, pp.32-34, (1996).

[36] Mohanty, A.B., (ed.), Madalapanji, PrachiSamiti; Cuttack,1932, Reprinted at Orissa SahityaAkademi; Bhubaneswar, p.21, (2001).

[37] Das, R.K., Legends of Jagannatha, PragatiUdyaga; Bhadrak, p.94, (1978).

[38] Routray, B. "Traditions in Paintings", in Art Tradition of Orissa, Ed. Orissa SahityaAkademi; Bhubaneswar, pp.59-60, (1982). 
[39] Mansingh, M., OdiaSahityaraItihasa (Odia), Cuttack, p.331,(1952).

[40] Dash, S.N. (ed.), Reports and Notes on ShriJagannatha Temple, Puri, Bhubaneswar, p.41, (2018).

[41] Mahapratra, K.N. , “Antiquity of Jagannatha-Puri As A Place of Pilgrimage'”, in JOHR, Vol. III, No-I, p21, (June; 1954/55).

[42] Hein , E., "Temple, Town and Hinter Land in Puri”, in A. Eschmann, H. Kulke\& G.C. Tripathy (eds.), The Cult of Jagannatha and the Regional Tradition of Orissa, New Delhi, p.439, (1978).

Citation: Dr. Ratnakar Mohapatra, Brentford AlemAtemkeng. “Jagannatha Dhama of India: A Study on History and Culture”. International Journal of History and Cultural Studies (IJHCS). vol 6, no. 1, 2020 , pp. 28-36 doi: DOI: http://dx.doi.org/10.20431/2454-7654.0601004.

Copyright: () 2020 Authors. This is an open-access article distributed under the terms of the Creative Commons Attribution License, which permits unrestricted use, distribution, and reproduction in any medium, provided the original author and source are credited. 